\title{
Pembuatan Media Pembelajaran Berbasis Komputer untuk Materi Sifat Asam Basa dan Garam Kelas VII Tingkat SMP
}

\author{
Diterima 27 Maret 2018, Disetujui 2 April 2018, Dipublikasikan April 2018
}

\author{
K Muslim ${ }^{1, a)}$, S Syukri ${ }^{2}$, dan Iswendi ${ }^{2}$ \\ ${ }^{1}$ Departemen Kimia, Universitas Pendidikan Indonesia, Jl. Dr. Setiabudi No. 229, \\ Bandung 40154, Indonesia \\ ${ }^{2}$ Departemen Pendidikan Biologi, Institut Teknologi Nusantara, Jl. Dr. Sutomo No. \\ 100, Bandung 40154, Indonesia \\ ${ }^{a)}$ E-mail: khairani.muslim@gmail.com
}

\begin{abstract}
Abstrak. Salah satu materi pokok pada IPA SMP adalah sifat asam, basa dan garam. Media berbasis computer yang dirancang ini menggunakan program aplikasi Macromedia flash 8 . Media ini disajikan dengan simulasi eksperimen sederhana yang dapat memvisualisasikan kondisi yang sebenarnya, sehingga dapat membantu siswa untuk menggunakan media ini hingga akhir secara mudah dan aman. Tujuan dari penelitian ini adalah menghasilkan sebuah media berbsasis computeryang didukung dengan eksperimen sederarhana dan soal-soal pengayaan yang interaktif. Jenis Penelitian ini adalah Research and Development (R \& D). Sampel penelitian ini adalah 35 siswa salah satu SMP di kota Padang. Intrumen penelitian yang digunakan adalah angket. Analisis data pada instrumen tersebut menggunakan analisis skala likert. Variabel dalam intrumen tersebut terkait dengan konten, motivasi dan praktikalitas dari media tersebut. Berdasarkan hasil penelitian didapat rata-rata keseluruhan pada media yang dibuat tersebut sebesar 4,67. Hasil ini dapat mengintrepetasikan sebuah media tersebut layak diguakan dalam pembelajaran khususnya pada materi sifat asam, basa dan garam.
\end{abstract}

\section{Pendahuluan}

Kata kunci: Media berbasis komputer, asam, basa, dan garam, macromedia flash 8

Hakikat sains merupakan kaitan antara fakta, konsep, dan posedural untuk membangun pengetahuan sains itu sendiri. Ilmu Pengetahuan Alam dan Ilmu pengetahuan Sosial dikembangkan sebagai mata pelajaran integrative scince dan integrative social studies, bukan sebagai pendidikan disiplin ilmu (kemendikbud: 2013). Keduanya sebagai pendidikan berorientasi aplikatif, pengembangan kemampuan berfikir. Kemampuan belajar, rasa ingin tahu, dan pengembangan sikap peduli dan bertanggung jawab terhadap lingkungan sosial dan alam.

Permendiknas Nomor 22 Tahun 2006 mengharapkan pembelajaran IPA/ sains dapat menumbuhkan kemampuan berpikir, bekerja dan bersikap ilmiah serta mengkomunikasikannya sebagai aspek penting kecakapan hidup. Namun, berdasarkan fakta di lapangan di salah satu SMP di kota Padang, penulis menemukan beberapa permasalahan khususnya dalam menerapkan kurikulum 2013. Kurikulum 2013 memiliki tujuan mendasar untuk membangun kemampuan siswa yang aktif melalui kompetensi siswa dalam sikap, keterampilan, dan pengetahuan yang diintegrasikan dalam kegiatan pembelajaran. Sehingga diharapkan siswa mampu aktif mengembangkan kemampuannya dalam pembelajaran IPA. Namun, dari beberapa masalah yang ditemukan di salah satu SMP di Kota Padang, khususnya siswa SMP kelas VII, kemampuan komptensi siswa dalam pembelajaran IPA belum tercapai sepenuhnya. Hal ini terlihat dalam di dalam proses pembelajaran, aktivitas siswa terlihat kurang menggali informasi sendiri, kurangnya keaktifan dan motivasi belajar. Sehingga hal ini berdampak pada hasil belajar siswa itu sendiri.

Salah satu Materi pokok pada silabus IPA SMP adalah sifat Asam, Basa dan garam. Kompetensi dasar pembelajaran ini adalah siswa mampu mengelompokkan sifat larutan asam, larutan basa dan larutan garam melalui alat dan indikator pencapaian kompetensi yang tepat. Ketidakmampuan guru untuk menjelaskan konsep-konsep ini dengan kemasan yang menarik, dapat 
Sekretariat: Jurusan Pendidikan IPA, Fakultas Matematika dan Ilmu Pengetahuan Alam, Universitas Negeri Padang - Jl. Prof. Dr. Hamka, Air Tawar Padang, Sumatera Barat

E-mail :prodiipa16@gmail.com, Halaman website : http://www.semesta.ppj.unp.ac.id/index.php/semesta.

Jurnal SEMESTA, Vol.01, No.01, 2017 pp. 13-17

menurunkan motivasi siswa dalam belajar. Sehingga dapat menurunkan aktivitas siswa dalam pembelajaran. Jika hal ini berkelanjutan bisa menyebabkan pelajaran kimia menjadi kurang disukai siswa. Maka harapan untuk menghasilkan output yang berkualitas dan memiliki kecakapan pun tidak akan tercapai. Untuk itu, guru harus mampu menyampaikan konsep-konsep IPA dalam kemasan yang menarik dan menciptakan suasana pembelajaran yang menyenangkan untuk menarik minat dan perhatian siswa.

Materi sifat asam, basa dan garam ini sesungguhnya disajikan dengan praktikum sederhana, tetapi akibat keterbatasan sarana dan prasarana di laboratorium di sekolah tidak dapat dilaksanakan. Pada materi sifat asam, basa dan garam ini alternatif yang digunakan guru dalam pembelajaran adalah metode ceramah dan didukung dengan media yaitu buku dan bahan ajar. Sebagai alternative lain, belum tersedia media berbasis komputer khususnya pada materi sifat asam, basa dan garam untuk membantu pembelajaran, sehingga siswa cendrung untuk menghafal dan kurang dalam aktifitas belajar. Akibatnya hasil belajar siswa untuk materi sifat asam, basa dan garam kurang baik. Jika persoalan diatas tidak dicarikan solusinya, maka akan berdampak pada lemahnya kemampuan berpikir siswa. Hal ini akan berpengaruh pada materi selanjutnya terutama pada bidang kimia tingkat SMA.

Untuk mengatasi permasalahan di atas, alternatif yang dapat diaplikasikan yaitu penggunaan media pembelajaran seperti charta, modul, dan media berbasis komputer. Dari ketiga opsi media pembelajaran tersebut, penulis tertarik membuat media pembelajaran berbasis komputer karena komputer dapat memadukan berbagai media termasuk gambar, animasi, dan teks dalam suatu penyajian, sehingga komputer lebih dikenal sebagai multimedia. Dengan bantuan gambar dan animasi, percobaan dapat divisualisasikan sehingga setiap konsep diharapkan dapat dipahami dengan baik. Menurut Arsyad (2009 : 91) Visualisasi adalah rekayasa dalam pembuatan gambar, diagram atau animasi untuk penampilan suatu informasi. Secara umum, visualisasi dapat berupa gambar baik yang bersifat abstrak maupun nyata. Dengan visualisasi pada media pembelajaran ini maka siswa diajak berfikir dan menemukan konsep untuk menarik kesimpulan. Nantinya dapat menyelesaikan latihan untuk memantapkan konsep yang telah diperoleh. Media pembelajaran berbasis komputer ini memungkinkan siswa melakukan kegiatan belajar secara mandiri, sendiri, kapan saja dan dimana saja tanpa terikat waktu.

Media pembelajaran sifat asam basa dan garam yang berbasis komputer ini, berisikan kompetensi, animasi tentang konsep-konsep materi, rangkuman, dan latihan. Media ini dirancang dan dibuat sedemikian rupa untuk menghasilkan tampilan dengan efek warna dan tulisan yang menarik, gambar serta animasi. Tujuannya untuk memahami konsep-konsep pelajaran yang divisualkan melalui media tersebut. Selain itu, adanya pertanyaan-pertanyaan yang bersifat interaktif dan memotivasi serta menuntun siswa menemukan dan menyimpulkan konsep yang ada dalam materi asam, basa dan garam. Media ini diharapkan dapat meningkatkan motivasi belajar siswa dan dapat meningkatkan hasil belajar. Dengan penggunaan media ini siswa juga dapat belajar mandiri dan dapat digunakan berulang-ulang karena dapat disimpan dalam media penyimpanan data seperti Compact Disc (CD) dan Flashdisc. Pembuatan media pembelajaran kimia berbasis komputer telah dilakukan antara lain oleh Shakdiah (2012) pada pokok bahasan zat aditif pada makanan dan Verananda (2012) pada pokok bahasan sifat koligatitif larutan non elektrolit. Dari hasil penelitian dilaporkan bahwa kedua media pembelajaran berbasis komputer tersebut layak digunakan untuk pembelajaran kimia. Berdasarkan latar belakang di atas, penulis tertarik melakukan penelitian dengan merancang dan membuat media pembelajaran berbasis komputer untuk materi asam basa dan garam yang dapat digunakan secara mandiri dan membantu guru dalam mengajar, dengan judul "Pembuatan Media Pembelajaran Berbasis Komputer untuk Materi Sifat Asam, Basa dan Garam Tingkat Sekolah Menengah Pertama (SMP)"

\section{Metode Penelitian}

Penelitian ini adalah penelitian pengembangan atau Reserch and Development (R\&D). Artinya penelitian yang digunakan untuk menghasilkan produk tertentu dan menguji kelayakkan produk tersebut (Sugiyono 2006: 40. Penelitian ini dilakukan di salah satu Sekolah Menengah Pertama di kota Padang. Subjek penelitian terdiri dari siswa Sekolah Menengah Pertama (SMP) Negeri 12 
Sekretariat: Jurusan Pendidikan IPA, Fakultas Matematika dan Ilmu Pengetahuan Alam, Universitas Negeri Padang - Jl. Prof. Dr. Hamka, Air Tawar Padang, Sumatera Barat

E-mail :prodiipa16@gmail.com, Halaman website : http://www.semesta.ppj.unp.ac.id/index.php/semesta.

Jurnal SEMESTA, Vol.01, No.01, 2017 pp. 13-17

Padang berjumlah 30 orang. Instrumen penelitian yang digunakan adalah angket dan dianalisis dengan skala likert. Angket berguna untuk Uji kelayakan media. Angket merupakan teknik pengumpulan data yang dilakukan dengan cara memberi seperangkat pertanyaan atau pernyataan tertulis kepada responden untuk dijawab. Angket yang diberikan adalah angket yang sebelumnya telah divalidasi oleh dosen pembimbing yang dibuat berdasarkan kisi-kisi, maka instrument yang dibuat itu sudah dapat dianggap mempunyai validitas logis (Lufri, 2007: 114).

Media pembelajaran berbasis komputer yang akan dibuat terlebih dahulu melalui beberapa tahapan:

1. Merancang media pembelajaran

2. Membuat Media Berbasis Komputer dengan Macromedia flash profesional 8

3. Uji Kelayakan Media.

\section{Hasil dan Pembahasan}

Media pembelajaran telah dibuat dengan bantuan program Macromedia Flash Professional 8.0. Media ini berisi SK, KD, indikator, tujuan pembelajaran, gambar dan pertanyaan-pertanyaan bersifat interaktif. Media ini, dapat menuntun siswa menemukan dan menyimpulkan konsep pada materi sifat asam, basa dan garam. Selain itu, terdapat rangkuman dan soal-soal latihan yang dapat meningkatkan pemahaman siswa. Media ini dapat disimpan dalam berbagai bentuk media penyimpanan data seperti Compact Disk (CD) dan Flashdisk.

Uji kelayakan media pembelajaran sifat asam, basa dan garam diujikan kepada siswa kelas VII SMP N 12 Padang yang berjumlah 30 orang. hasil analisis data tersebut dikelompokkan ke dalam pernyataan-pernyataan dan dideskripsikan pada Tabel 1.

Tabel 1. Hasil Nilai Kelayakan Angket Siswa

\begin{tabular}{|c|c|c|c|c|}
\hline No & Item & No item & $\begin{array}{c}\text { Nilai } \\
\text { kelayakan }\end{array}$ & $\begin{array}{c}\text { Interpetasi } \\
\text { data }\end{array}$ \\
\hline 1 & Isi & $1,2,3,4,5,6$ & 4,71 & Sangat Layak \\
\hline 2 & Motivasi & $\begin{array}{l}7,8,9 \\
10,11\end{array}$ & 4,6 & Sangat Layak \\
\hline 3 & Kepraktisan & $9,12,13$ & 4,66 & Sangat Layak \\
\hline \multirow[t]{2}{*}{4} & Bentuk & 14,15 & 4,76 & Sangat Layak \\
\hline & & Nilai rata- & $a=4,67$ & Sangat Layak \\
\hline
\end{tabular}

Dari Tabel diperoleh nilai rata-rata analisis data angket siswa yaitu 4,67. Jika nilai ini diinterpretasikan pada kategori kelayakan, maka media pembelajaran berbasis komputer ini sangat layak digunakan dalam materi sifat asam, basa dan garam. Hasil analisis distribusi angket siswa mengenai media pembelajaran sifat asam, basa dan garam berdasarkan 4 kriteria media dengan indikator berbeda dapat dijelaskan sebagai berikut:

\subsection{Bentuk/Tampilan}

Media pembelajaran yang dinilai berdasarkan segi bentuk adalah tampilan media yang mencakup ukuran tulisan, simbol, gambar atau animasi, dan bahasa yang digunakan dalam media pembelajaran berbasis komputer. Pengombinasian aspek inilah yang akan memotivasi siswa dalam proses pembelajaran. Penyajian informasi dengan mengkombinasikan gambar, warna, dan tulisan dapat menarik perhatian siswa dan memperjelas materi pelajaran sehingga siswa dapat mengingat materi pelajaran tersebut. (Susilana, 2007:13).

Berdasarkan analisis angket yang diberikan kepada siswa dari segi bentuk diperoleh nilai kelayakan 4,76. Hal ini mengindikasikan bahwa media pembelajaran sifat asam, basa dan garam ini sangat layak dari segi bentuk. Indikator gambar yang digunakan dalam media pembelajaran berbasis komputer adalah indikator yang memiliki tingkat kelayakan paling tinggi dibandingkan dengan indikator lain dari segi bentuk. 
Sekretariat: Jurusan Pendidikan IPA, Fakultas Matematika dan Ilmu Pengetahuan Alam, Universitas Negeri Padang - Jl. Prof. Dr. Hamka, Air Tawar Padang, Sumatera Barat

E-mail :prodiipa16@gmail.com, Halaman website : http://www.semesta.ppj.unp.ac.id/index.php/semesta.

Jurnal SEMESTA, Vol.01, No.01, 2017 pp. 13-17

Dengan menggunakan tombol, siswa dapat menggunakan media dengan mudah. Hal itu disebabkan karena tombol yang terdapat dalam media tidak terlalu banyak variasi, sehingga tidak menimbulkan ragu-ragu dan rasa takut kepada siswa dalam menggunakan tombol tersebut. Untuk menjalankan program latihan dalam media ini Siswa manyatakan bahwa bentuk, warna dan tata letak tombol dalam media cukup menarik dan sudah tepat.

Beberapa saran dari siswa dan guru mengenai bentuk media adalah warna background yang digunakan agar disesuaikan. Hal ini diharapkan animasi percobaan pada media menjadi lebih jelas. Selanjutnya dari ukuran tulisan, nama-nama larutan diharapkan diperbesar. Agar terlihat oleh siswa hingga kebelakang jika menggunakan LCD dalam pembelajaran sifat asam, basa dan garam.

\subsection{Isi}

Pembelajaran berbasis komputer yang dibuat harus memperhatikan isi atau cakupan materi dalam media. Isi yang dimaksudkan disini adalah mengenai kesesuaikan gambar, animasi, dan materi dengan standar kompetensi, kompetensi dasar, indikator pada Kurikulum Tingkat Satuan Pendidikan. Berdasarkan hasil analisis data angket mahasiswa dan guru didapatkan nilai kelayakan media pembelajaran berbasis komputer dari segi isi adalah 4,71. Hal ini menunjukkan bahwa materi, gambar, animasi yang digunakan dalam media pembelajaran berbasis komputer telah sesuai dengan SK, KD, dan indikator pada Kurikulum Tingkat Satuan Pendidikan.

Isi pada media ini diberi pertanyaan-pertanyaan bersifat interaktif sehingga siswa dapat menemukan dan menyimpulkan konsep tersebut. Dengan demikian, Pengalaman belajar siswa akan tahan lama dalam ingatan apabila menemukan sendiri suatu konsep yang mereka pelajari (Jalius, 2009:66).

Secara garis besar siswa menyatakan paham terhadap isi dari materi sifat asam, basa dan garam. Harapan dari beberapa guru IPA di SMP berharap akan ada media pembelajaran berbasis komputer untuk materi yang terkait dengan kimia. Dengan penggunaan media ini dapat membantu guru dalam proses pembelajaran kimia disekolah.

\subsection{Motivasi}

Motivasi yang dimaksud berhubungan dengan termotivasi siswa dalam belajar. Penggunaan media pembelajaran dalam proses belajar dapat menimbulkan motivasi belajar, interaksi yang lebih langsung antara siswa dan lingkungannya, dan kemungkinan siswa untuk belajar sendiri-sendiri sesuai dengan kemampuan dan minat (Arsyad, 2009 : 26). Berdasarkan hasil analisis data angket siswa diperoleh nilai kelayakan dari segi motivasi adalah 4,66. Hasil analisis data kelayakan tersebut menunjukkan bahwa media pembelajaran berbasis komputer materi sifat asam, basa dan garam dari segi motivasi sangat layak digunakan sebagai media pembelajaran di kelas VII tingkat SMP N 12 Padang.

Media berbasis komputer ini menyajikan gambar animasi percobaan. Akibatnya, saat menggunakan media siswa merasakan senang dan seolah-olah sedang pratikum dilaboratorium. Selain itu, media ini dapat memberikan respon langsung dari kegiatan siswa saat menggunakan media. Sehingga siswa dapat termotivasi dalam belajar sifat asam, basa dan garam dan dapat menarik kesimpulan. Hal ini sesuai dengan keunggulan dari media berbasis komputer salah satunya yaitu dapat membuat siswa termotivasi dalam belajar dan menjadi aktif karena adanya gambar-gambar animasi, warna dan suara. (Arsyad, 1997:54).

\subsection{Kepraktisan}

Kepraktisan yang dimaksud adalah media ini dapat membantu siswa dalam belajar, baik dalam kelas maupun secara individual dengan waktu yang lebih efisien dan dapat digunakan kapan dan dimana saja kepraktisan penyajian dan penggunaannya. Praktis dalam hal ini adalah media tidak hanya dapat digunakan oleh guru tapi yang lebih penting dapat pula digunakan siswa (Sadiman, 1996: $10)$.

Berdasarkan hasil analisis data angket siswa diperoleh nilai kelayakan dari segi motivasi adalah 4,76. Hasil analisis data kelayakan tersebut menunjukkan bahwa media pembelajaran berbasis 
Sekretariat: Jurusan Pendidikan IPA, Fakultas Matematika dan Ilmu Pengetahuan Alam, Universitas Negeri Padang - Jl. Prof. Dr. Hamka, Air Tawar Padang, Sumatera Barat

E-mail :prodiipa16@gmail.com, Halaman website : http://www.semesta.ppj.unp.ac.id/index.php/semesta.

Jurnal SEMESTA, Vol.01, No.01, 2017 pp. 13-17

komputer materi sifata asam, basa, dan garam dari segi motivasi sangat layak digunakan sebagai media pembelajaran di kelas VII di SMP N 12 Padang.

Dari segi kepraktisan adalah indikator penggunaan media pembelajaran dapat digunakan secara berulang-ulang. Hal ini dapat membuat kegiatan pembelajaran lebih efektif dan efisien. Media pembelajaran berbasis komputer dapat disimpan di dalam flasdisk, Compact Disk (CD), Digital Video Disk (DVD), atau kartu memori, sehingga media ini dapat digunakan kapanpun dan dimanapun.

Hasil uji kelayakan media pembelajaran berbasis komputer secara keseluruhan memiliki nilai kelayakan yang sangat layak, tetapi media pembelajaran ini masih ditemui kendala bagi siswa yaitu malas mencatat informasi yang terdapat dalam media. Siswa lebih memilih menjawab pertanyaan langsung untuk menemukan kesimpulan. Disamping itu sarana dan prasarana di sekolah masih terbatas seperti ketersediaan LCD, komputer, dan lain-lain.

Penggunaan media pembelajaran berbasis komputer ini membutuhkan pengawasan yang lebih oleh guru dalam proses pembelajaran. Hal ini disebabkan karena kecenderungan beberapa siswa yang tidak fokus memperhatikan media. Siswa bersikap seperti ini karena siswa tersebut terbiasa dengan metode guru yang ceramah didepan kelas dan penjelasan yang lengkap oleh guru dibandingkan menggunakan media pembelajaran berbasis komputer. Media berbasis komputer menuntut siswa untuk menarik kesimpulan sendiri. Guru hanya sebagai fasilitator yang membimbing siswa untuk menemukan konsep sifat asam, basa dan garam sendiri dengan bantuan media berbasis komputer.

\section{Kesimpulan}

Berdasarkan hasil penelitian dan analisis data, dapat disimpulkan bahwa materi sifat asam, basa dan garam dapat dibuatkan media pembelajaran berbasis komputer. Media sifat asam, basa dan garam berbasis komputer layak digunakan dalam proses pembelajaran di kelas VII SMP.

\section{Ucapan Terima Kasih}

Penulis mengucapkan terima kasih kepada Bapak Syukri S., M. Si dan Bapak Dr. Iswendi, M. Sc serta seluruh staf pengajar jurusan kimia FMIPA UNP.

\section{Daftar Pustaka}

Arsyad, Azhar. 2009. Media Pembelajaran. Jakarta: Raja Grafindo Persada.

Jalius, Ellizar. (2009). Pengembangan Program Pembelajaran. Padang: UNP Press.

Lufri. (2007). Kiat Memahami dan Melakukan Penelitian. Padang: UNP Press.

Sadiman, Arief dkk. (1996). Media Pendidikan, Pengertian, Pengembangan dan Pemanfaatannya. Jakarta: Raja Grafindo Persada.

Shakdiah, Nur. (2012). "Pembuatan Media Pembelajaran Berbasis Komputer Untuk Materi Zat Aditif Makanan ." Skripsi. Padang: UNP.

Sugiyono. (2006). Metode Penelitian Kuantitatif, Kualitatif dan R\&D. Bandung: CV Alfabeta

Susilana, Rudi \& Riyana, Cepi. (2007). Media Pembelajaran: Hakikat, Pengembangan, Pemanfaatan dan Penilaian. Bandung: CV. Wacana Prima.

Verananda, Elsa (2012). "Pembuatan Media Pembelajaran Compact Disc (Cd) Interaktif Pada Pokok Bahasan Sifat Koligatif Larutan Nonelektrolit Di Sma.” Skripsi. Padang : UNP.

Zafri.1999. Metode Penelitian Pendidikan. Padang: UNP Press 